\title{
The impacts of climate change on Greek airports
}

\author{
Guy Gratton ${ }^{1}$ (D) $\cdot$ Anil Padhra ${ }^{2} \cdot$ Spyridon Rapsomanikis $^{3} \cdot$ Paul D. Williams $^{4}$
}

Received: 10 January 2019 / Accepted: 17 December 2019 / Published online: 13 February 2020

(C) The Author(s) 2020

\begin{abstract}
Time series of meteorological parameters at ten Greek airports since 1955 indicated the level of climate change in the Eastern Mediterranean area. Using this data, take-off performance was analysed for the DHC-8-400 - a typical short range turboprop airliner, and the A320, a typical medium scale turbofan airliner. For airports with longer runways, a steady but unimportant increase in take-off distances was found. For airports with shorter runways, the results indicate a steady reduction in available payload. At the most extreme case, results show that for an Airbus A320, operating from the, relatively short, $1511 \mathrm{~m}$ runway at Chios Airport, the required reduction in payload would be equivalent to 38 passengers with their luggage, or fuel for 700 nautical miles $(1300 \mathrm{~km})$ per flight, for the period between the A320's entry to service in 1988 and 2017. These results indicate that for airports where aeroplane maximum take-off mass is a performance limited function of runway length, and where minimum temperatures have increased and/or mean headwind components decreased, climate change has already had a marked impact on the economic activity in the airline industry. Similar analyses could be usefully carried out for other runway-length-limited airports, which may often include island airports. It is also noted that previous research has only considered temperature effects, and not wind effects. Wind effects in this study are less significant than temperature, but nonetheless have an effect on both field performance noise and pollution nuisance around airports.
\end{abstract}

Keywords Airport · Runway · Take-Off Performance · Aeroplane · A320 · DHC-8-400 · Greece · Mediterranean

\section{Introduction: Why climate change matters to airport operations}

Emissions of gaseous pollutants, greenhouse gases and particulate matter from the aviation transport sector, affect the current and will affect the future climate. The net effect is increasing tropospheric and boundary layer temperatures and decreasing lower stratosphere temperatures.

Electronic supplementary material The online version of this article (https://doi.org/10.1007/s10584-01902634-z) contains supplementary material, which is available to authorized users.

Guy Gratton

guy.gratton@cranfield.ac.uk

Extended author information available on the last page of the article 
Conversely, climate change affects aeroplane performance and by inference the whole of the aviation sector.

Recent publications indicate that jetstreams and stationary wave pattern winds at cruising altitudes are changing, particularly with increased carbon dioxide forcing. Modified wind shears consequently modify both mean strength and frequency of clear-air turbulence (Williams and Joshi 2013), (Williams 2017) (Storer et al. 2017), (Lee et al. 2019). This will also modify journey times (Karnauskas et al. 2015), (Williams 2016), (Irvine et al. 2016).

Aeroplane performance during take-off and landing (the transition between the runway and standard departure and arrival paths, normally to or from a height $10 \mathrm{~m}$ above the surface) is directly impacted by lower atmosphere temperature, pressure and the wind vector. This means that increased temperatures, reduced pressure and reduced headwind component all increase takeoff and landing distances. Furthermore, increased temperature and reduced pressure (otherwise expressed: increased density altitude) result in shallower climb angles (Swatton 2008).

Recent publications indicate future reductions in aircraft performance due to climate change related increases in temperature (Zhou and et. al. 2018) (Coffel et. al. 2017). It is also known that climate change is already observable in the Mediterranean region (Lelieveld et. al. 2012), but its impact on aviation in that region has not previously been assessed.

The present work considers historic changes in temperature and wind conditions at ten Greek airports and determines the effect of these changes on the performance of a typical turboprop aeroplane (a de Havilland Canada DHC-8-400 fitted with Pratt \& Whitney Canada PW150A engines rated at $4850 \mathrm{shp}(3620 \mathrm{~kW})$ (Federal Aviation Administration 2004) and a typical turbofan aeroplane (an Airbus A320-231 aircraft fitted with IAE V2527-A5 engines rated to 27,000 lbf (120 $\mathrm{kN}$ ) thrust (European Union Aviation Safety Authority 2018). It also projects the effect of these changes in the local climate to future airplane operations on these airports.

It is beyond the scope of this study to formally attribute the observed secular headwind changes to anthropogenic carbon dioxide emissions. However, we note that a meta-analysis of 148 studies reporting terrestrial near-surface wind speed trends across the globe found that winds have generally weakened over land over the past few decades, a phenomenon referred to as "global stilling" (McVicar and et. al. 2012). In Greece, in particular, the wind speed at 20 measurement sites at a height of $2 \mathrm{~m}$ has decreased over the period 1959-2001, consistent with our findings at airports. A possible explanation for these wind trends is that anthropogenic climate change is warming the poles faster than the tropics in the lower atmosphere, weakening the mid-latitude north-south temperature difference and consequently reducing the thermal wind at low altitudes (Lee et al. 2019). Another possible explanation is that anthropogenic climate change is expanding the Hadley cells, pushing the fast winds associated with the storm tracks towards the poles and away from the midlatitude regions. A final possible explanation is an increase in surface roughness, caused by an increase in vegetation or (in our case) development around the airports. For the purposes of this paper, however, the main point of interest is that the wind vectors have modified.

\section{Methods}

The present work utilised weather data from ten Greek airports, for the longest period available, to the end of 2017. Time series varied from a shortest period of 28 years to a longest period of 62 years. For each year, the annual-mean daily minimum temperature was determined, as was the mean headwind component (the component of wind parallel with the runway in-use). 
Lower, night time temperatures and atmospheric components are employed as they are the best indicators for local climate change (Davy et al. 2016), and in particular, because they show the least day-to-day variation (Munasinghe et. al. 2012).

Those data were then used to determine changes in the performance for two aeroplane types: the de Havilland DHC-8-400 (a short range turboprop twin engine airliner) and an Airbus A320. At a representative mean-wind, mean-lowest-temperature condition (lowest temperature representing the shortest take-off distances, all other conditions being identical) take-off performance was calculated for both aeroplanes. Where runway length was sufficient to permit performance at the certified maximum take-off mass, this was calculated as take-off distance required (TODR); where runway length was limiting, this was calculated as a lower maximum take-off mass (MTOM). All certified aeroplanes have sets of scheduled performance data, determined and verified as part of the certification process. These data are then used to calculate (amongst other values) take-off distance for any given set of conditions. Those calculations are taught as part of pilot training (e.g. in ASA (Aeronautical Supplies and Academics (ASA) Inc 2018), CATS (Cranfield Aviation Training School (CATS) 2019)) and are required knowledge for all professional pilots. For this study, the manufacturer and authority approved performance data (Bombardier 2014; Bombardier 2011) were used for the DHC-8-400 and a locally developed performance model which had been validated using manufacturer data were also used for the A320. Inputs into these calculations are temperature, wind, runway slope, surface condition (with a default condition of dry and uncontaminated surface) and pressure (with a default condition corresponding to temperate International Standard Atmosphere (ISA) conditions related to a sea level condition of $1013.25 \mathrm{hPa}$ ).

The method used to determine the DHC-8-400 take off distance required (TODR) for airports with sufficient runway (hence not MTOM limited), was driven by the format of the Aircraft Operators Manual (Bombardier 2011), and may require adaptation for use on other aeroplane types, as there is not a universal common format for these manuals. This manual consisted of a large number of printed lookup tables, verified through flight testing, and inevitably designed to be used for normal operations, not research purposes. The order of actions was as follows:

1) For the aeroplane absolute MTOM of $29,257 \mathrm{~kg}$, a plot of still air TODR was determined versus temperature and the coefficients derived for that curve.

2) At the year's mean minimum temperature, a still air TODR was then calculated to a precision of $1 \mathrm{~m}$.

3) Graphs were plotted for a bracketing range of take-off distances and headwind components, and the intercept determined for the mean minimum temperature zero wind TODR for the given year. From that intercept, a new plot was derived of TODR versus headwind component, and the coefficients for that curve determined.

4) From these coefficients, and the mean headwind component for that year, a nominal TODR was determined, again to a precision of $1 \mathrm{~m}$.

5) TODR per year was then plotted and a best fit straight line determined (Fig. 4); this showed a mean increase rate in TODR of $2.4 \mathrm{~m}$ per year, or an increase of about $84 \mathrm{~m}$ per 2017 take-off since the type entered service in 1984.

6) This was done using points on a linear fit to the meteorological data for all airports, and for the airport showing the greatest impact (Chios) for each individual year.

The method used to determine maximum take-off mass (MTOM) for the DHC-8-400 from the runway length limited airport Naxos was necessitated by the format of the operator's manual The order of actions was as follows: 
1) Using mean wind for that year and the actual runway length, an equivalent "fixed wind" take off distance available (TODA) was determined to a precision of $1 \mathrm{~m}$.

2) Having prepared plots of TODA versus MTOM (maximum take-off mass) for a range of temperatures bracketing the temperature value of interest, a series of MTOM values were determined at each temperature, for the fixed wind TODA to a precision of $10 \mathrm{~kg}$.

3) A new graph was prepared for temperature versus MTOM at that year's mean fixed wind TODA; coefficients for a best fit curve were determined for that graph.

4) Using those coefficients and the mean minimum temperature for that year (to an accuracy of $0.01^{\circ} \mathrm{C}$ ) an MTOM was determined, at a precision of $1 \mathrm{~kg}$.

These methods are explained in greater detail with illustrations in supplementary material \#1.

Similar calculations using manufacturer data were used for the A320 with the help of a locally created performance model for an Airbus A320 as developed by the University of West London. The sequence of these calculations and an explanation of the model are detailed in supplementary material \#2.

\section{Results: Changing lower atmosphere conditions}

This study has considered ten Greek airports (data sourced from AIP Greece (Hellenic Civil Aviation Authority 2019), the Aeronautical Information Publication for Greece), all airports here have single (long enough to be commercially) useable asphalt runways, listed in Table 1.

All data were released and are freely available by the Hellenic National Meteorological Service (HNMS at www.hnms.gr) having been re-analysed according to WMO standards, quality managed to ISO 9001-2015.

\subsection{Lower atmosphere temperatures}

Figure 1 depicts annual means of daily minimum air temperature values, used to indicate climate change impact on aircraft performance. At all ten airports, minimum air temperature is increasing at a rate in the range 0.3 to $0.9^{\circ} \mathrm{C} /$ decade, with a mean minimum temperature increase of $0.59^{\circ} \mathrm{C} /$ decade.

\subsection{Surface wind vectors}

Figure 2 depicts the mean headwind component for the best runway for take-off (judged by alignment with the wind) for each year, throughout the time periods of interest. Headwinds reduce take-off and landing distances; tailwinds increase take-off and landing distances, so the reciprocal runway is normally used rather than accepting a tailwind situation. A normal working assumption is that crosswinds affect handling but not performance; most aeroplanes have a "demonstrated crosswind limit", a maximum value seen in flight testing which will then be used as advice by operators as they develop their own, often lower, operating limits. Typically for airliners, this will have a value in the order of 30-40 knots at which point the aircraft is required to divert or switch to a runway better aligned with the wind. For the two aircraft types discussed in this paper, the demonstrated limit is 38 knots for the A320 and 32 knots for the DHC-8-400. 


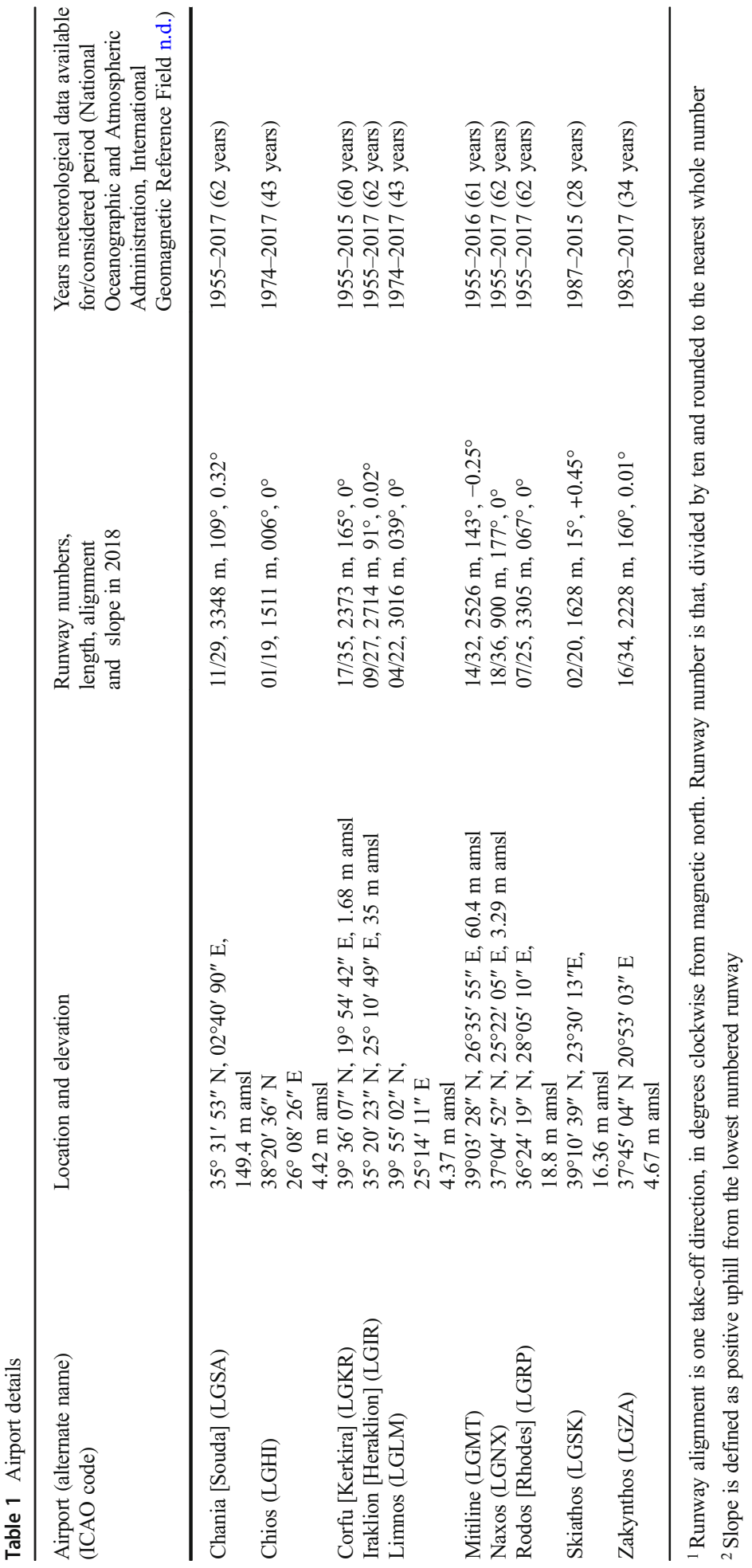



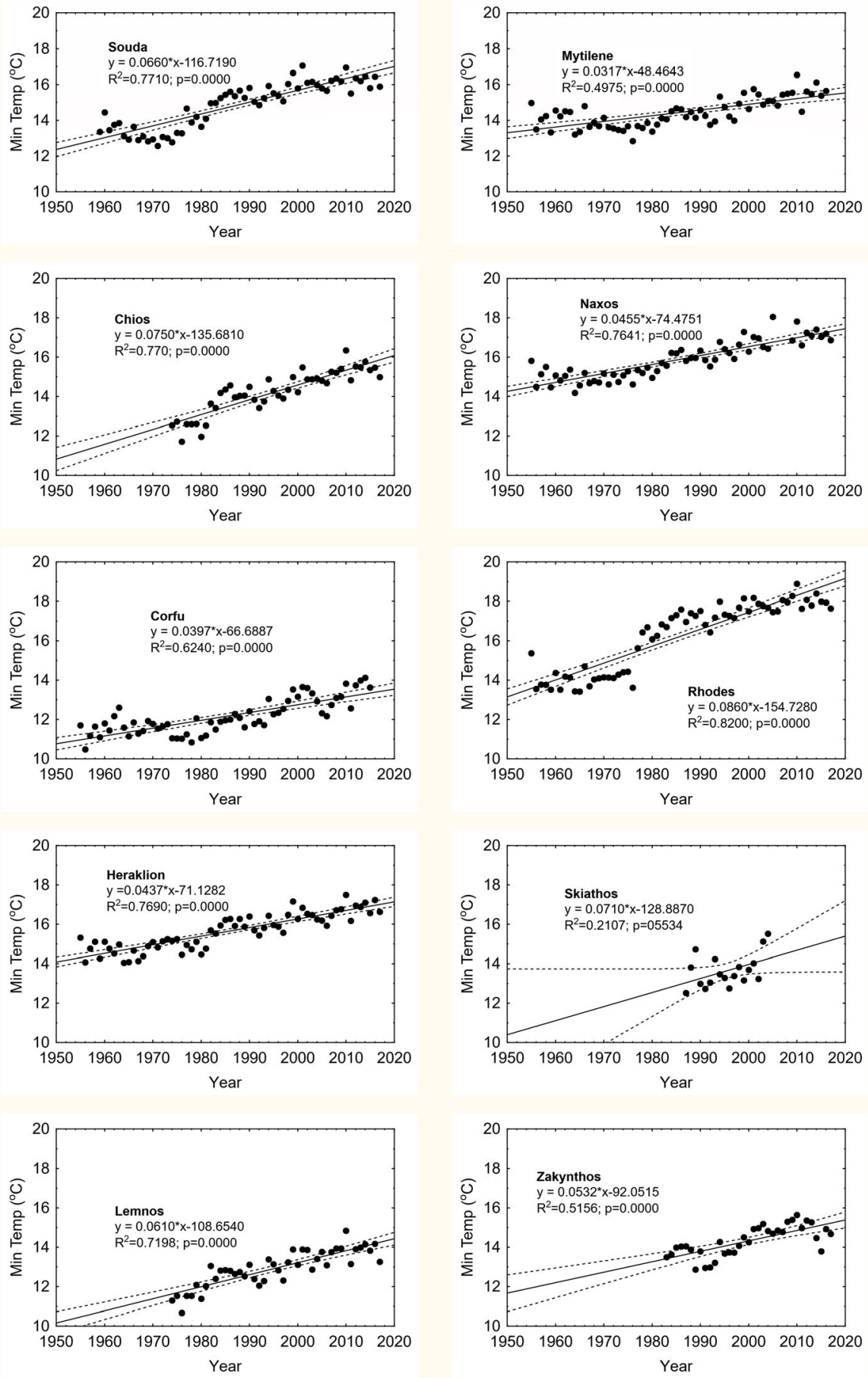

Fig. 1 Annual means of daily minimum temperatures for the studied time periods 

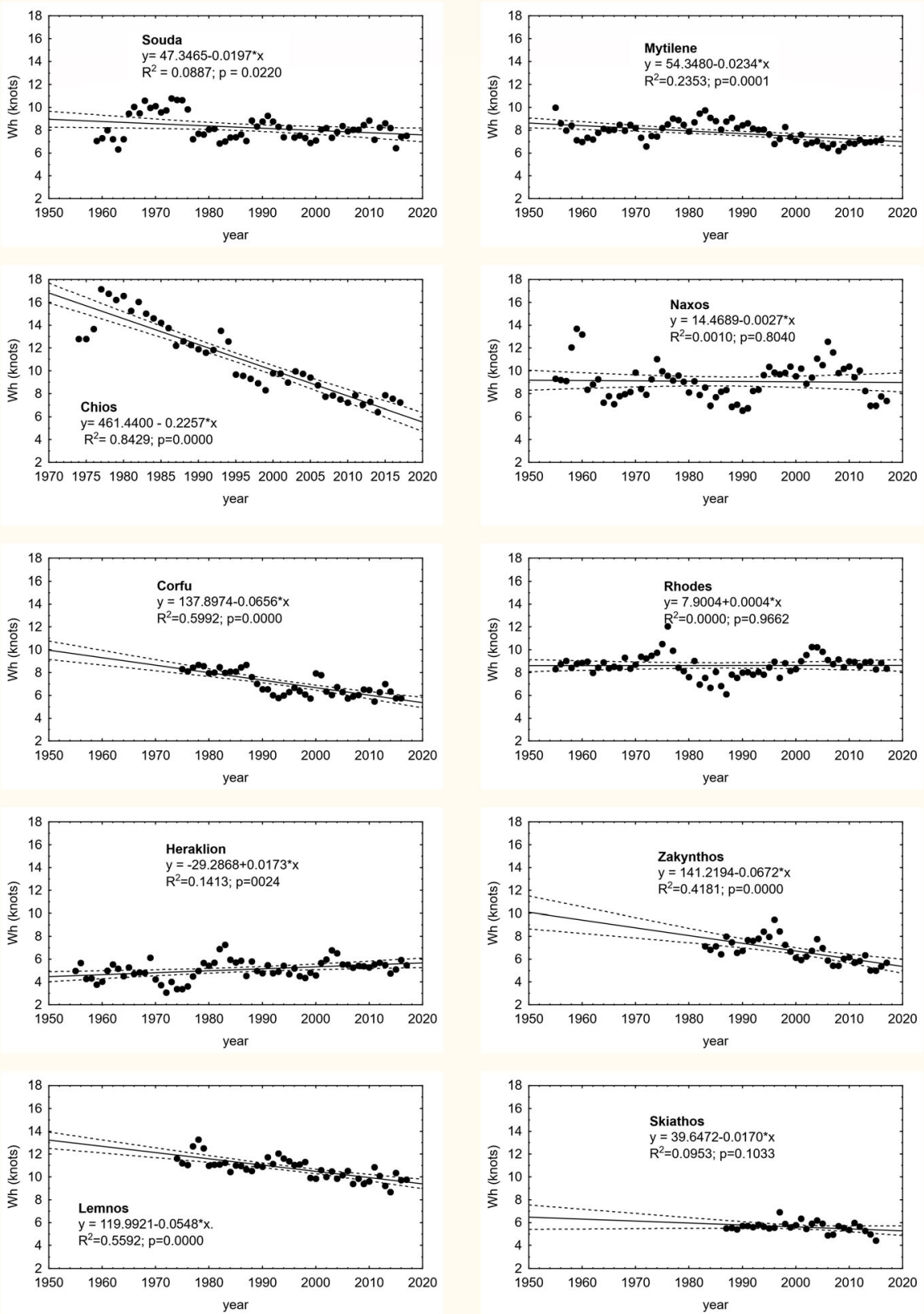

Fig. 2 Annual mean absolute headwind components WH. Note that the dominant wind direction at Skiathos is northerly, so take-offs there are normally uphill against a shallow south to north upslope

Figure 2 also shows that the mean headwind component decreases in six of the ten cases, indicating climatic change (Pirazzoli and Tomasin 2003) and is approximately neutral in the remaining four. The decrease was in the range -0.02 to 2.3 knots per decade mean headwind component with a mean of 0.49 knots per decade. 
Table 2 Results for airport where available payload changed for $\mathrm{dHC}-8-400$

\begin{tabular}{llllll} 
Airport & Years considered & MTOM at start $(\mathrm{kg})$ & MTOM at end $(\mathrm{kg})$ & $\begin{array}{c}\text { Difference }(\mathrm{kg}) \\
\text { Mer year }(\mathrm{kg} \cdot \mathrm{pa})\end{array}$ & $\begin{array}{l}\text { Mean change } \\
\text { per }\end{array}$ \\
\hline Naxos & $1955-2017$ & 24,766 & 24,618 & -148 & -2.4 \\
\hline
\end{tabular}

\section{Analysis}

\subsection{Impact on a turboprop aeroplane}

Take-off distance required [TODR] was calculated at the airports of interest for a de Havilland Canada DHC-8-400 (commonly called a Q400) using manufacturer's performance data for a $15^{\circ}$ flap (shortest field length) take-off. In each case, the calculations were made for maximum take-off mass [MTOM], from the earliest date for which meteorological data is available, for each annual mean value of minimum temperature and wind vector. Whilst these specific conditions are mean values, they were considered to provide a good indication of average change in the capability of the representative aeroplane, with time. In the single case of Naxos, where MTOM is compromised due to limiting take-off distance available [TODA], the calculations were carried out both for the time-series linear trend of meteorological parameters (and is shown in Table 2) and for each year's mean meteorological values (Fig. 3). Otherwise the calculations for TODR for each type of aeroplane and airport were solely carried out using the overall time-series linear trend of the meteorological parameters and are shown in Table 3.

Figure 3 shows the trend for MTOM with time at Naxos. This relationship shows moderate linearity and correlation $\left(R^{2}=0.19\right.$, compared with $R^{2}=1.4 \times 10^{-28} \approx 0$ against a level mean) and the trend is statistically significant $\left(p=4.36 \times 10^{-4}\right.$ using a two tailed $t$ test) whereby the aeroplane's maximum take-off mass decreases, but because of the aeroplane's inherent "short

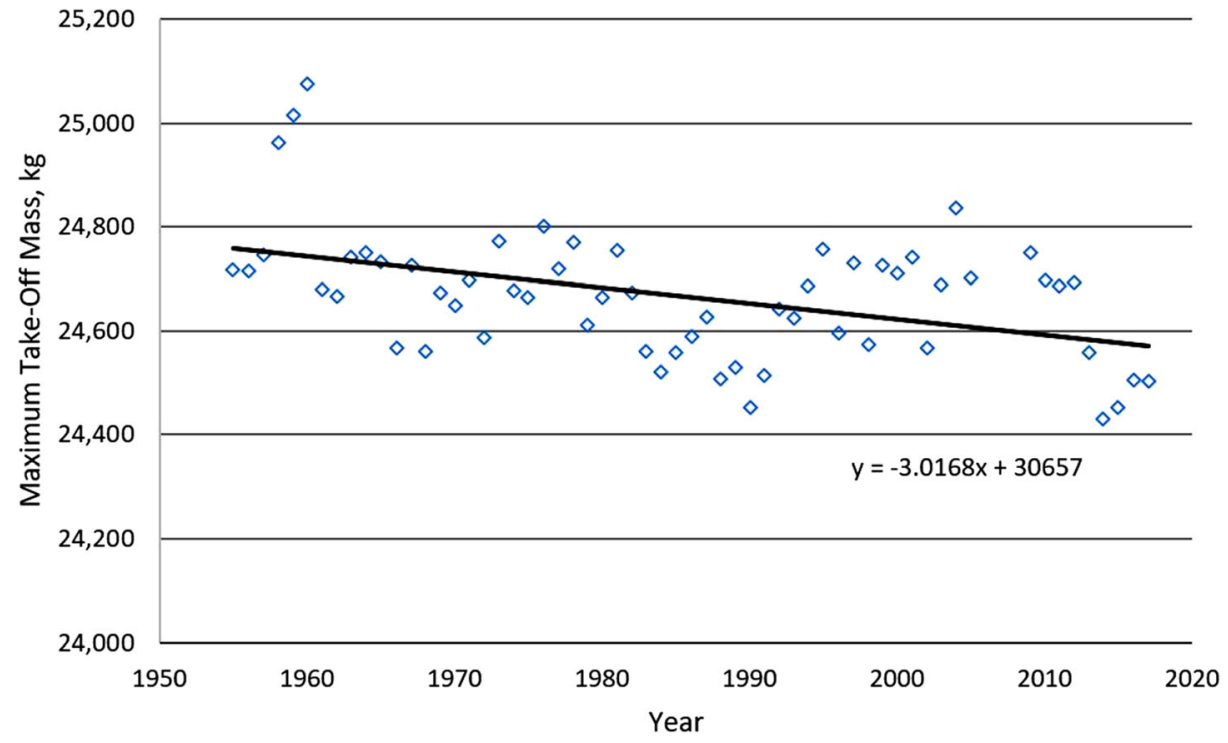

Fig. 3 Minimum temperature, mean wind maximum take-off mass per year for DHC-8-400 at Naxos 
Table 3 Results for airports where take of distance required changed for DHC-8-400

\begin{tabular}{llllll}
\hline Airport & $\begin{array}{l}\text { Years } \\
\text { considered }\end{array}$ & $\begin{array}{l}\text { TODR at start, } \\
\text { MTOM }(\mathrm{m})\end{array}$ & $\begin{array}{l}\text { TODR at end, } \\
\text { MTOM }(\mathrm{m})\end{array}$ & $\begin{array}{l}\text { Difference } \\
(\mathrm{m})\end{array}$ & $\begin{array}{l}\text { Mean change per } \\
\text { year }(\mathrm{m})\end{array}$ \\
\hline Chania & $1955-2017$ & 1310 & 1330 & +20 & +0.3 \\
Chios & $1974-2017$ & 1210 & 1320 & +110 & +2.6 \\
Corfu & $1955-2015$ & 1280 & 1340 & +60 & +1.0 \\
Iraklion & $1955-2017$ & 1340 & 1460 & +120 & +1.9 \\
Limnos & $1974-2017$ & 1250 & 1290 & +40 & +0.9 \\
Mitilini & $1955-2016$ & 1310 & 1350 & +40 & +0.7 \\
Rodos & $1955-2017$ & 1310 & 1390 & +80 & +1.3 \\
Skiathos & $1987-2015$ & 1380 & 1440 & +60 & +2.1 \\
Zakynthos & $1983-2017$ & 1300 & 1360 & & +60 \\
\hline
\end{tabular}

field" capability, this increase is usually seldom sufficiently at these low temperature/mean wind cases to compromise the ability to operate the aeroplane up to maximum take-off mass. However, in the case of Naxos, the daily minimum temperature climate change since 1955 has compromised payload by a mean 2.4 to $3.0 \mathrm{~kg}$ per take-off (depending upon calculation method, the higher value corresponding to the more detailed but considerably more calculation intensive method of calculating fully per year rather than calculating for a linear fit to temperature and wind trends), per annum or approximately $100 \mathrm{~kg}$ payload, per 2017 departure, since the type entered service in 1984 (Fig. 3). Over the recorded period, whilst Chania and Iraklion suffer from adverse temperature effects, they also enjoy proverse wind changes. In both cases, however, the rising temperature effect has greater impact than the strengthening headwind component.

Considering similarly the take-off performance per year for this aeroplane at Chios, this is shown at Fig. 4. This confirms strong correlation to the linear take-off distance conclusion of Table $3\left(R^{2}=0.88\right)$, and the trend is statistically significant $\left(p=1.04 \times 10^{-20}\right.$ using a two tailed

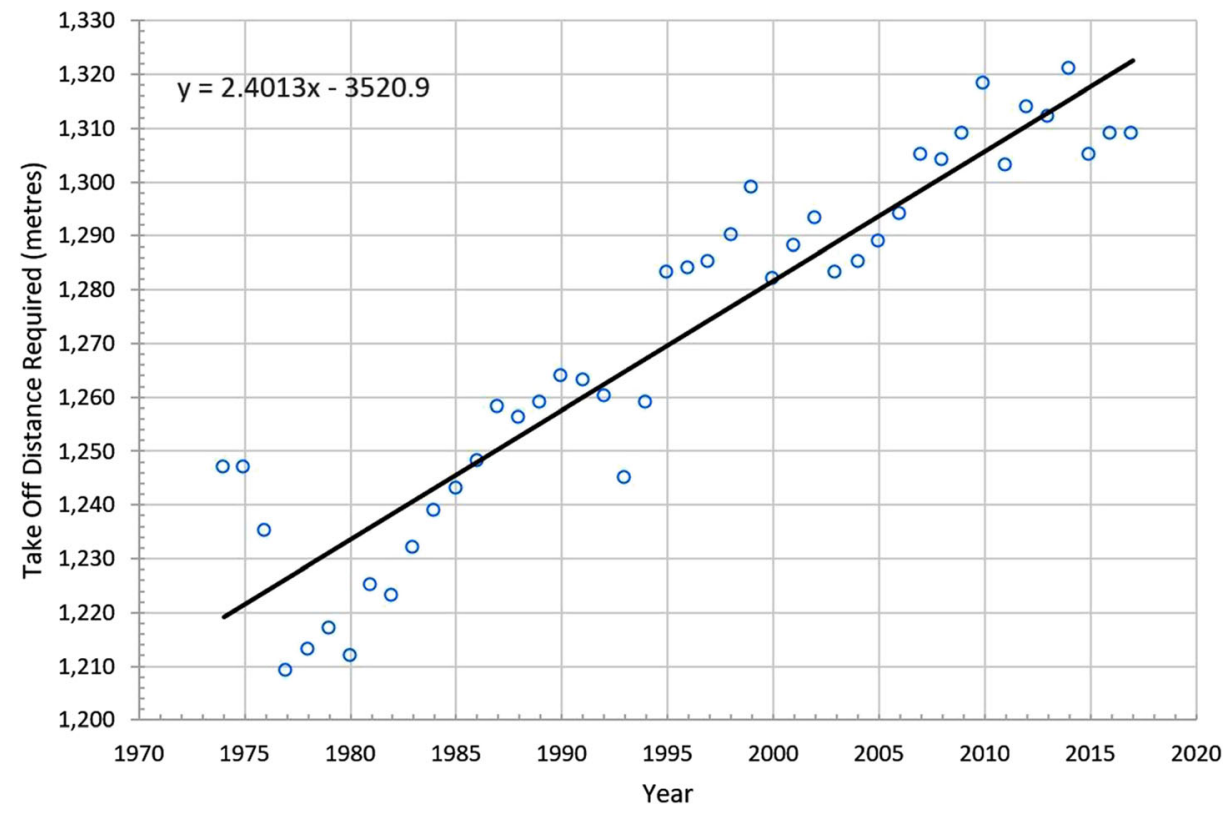

Fig. 4 Minimum temperature, mean wind take-off distance required per year for DHC-8-400 at Chios 
Table 4 Results for airports where available payload changes

\begin{tabular}{llllll}
\hline Airport & $\begin{array}{l}\text { Years } \\
\text { considered }\end{array}$ & $\begin{array}{l}\text { MTOM at start } \\
(\mathrm{kg})\end{array}$ & $\begin{array}{l}\text { MTOM at end } \\
(\mathrm{kg})\end{array}$ & $\begin{array}{l}\text { Difference } \\
(\mathrm{kg})\end{array}$ & $\begin{array}{l}\text { Mean change per year } \\
(\mathrm{kg} . \mathrm{pa})\end{array}$ \\
\hline Chios & $1974-2017$ & 74,780 & 69,056 & 5724 & -133 \\
Skiathos & $1987-2004$ & 73,648 & 73,340 & 308 & -18 \\
\hline
\end{tabular}

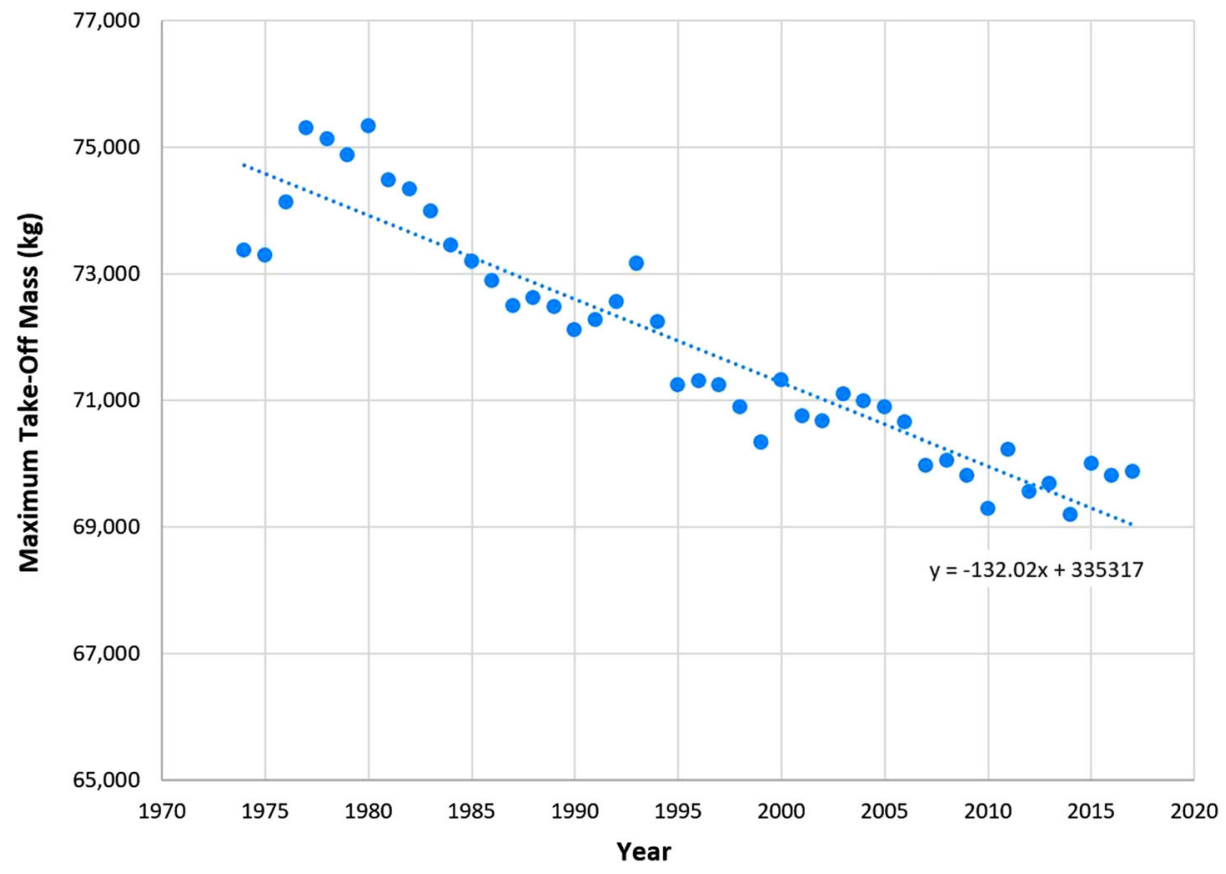

Fig. 5 Minimum temperature, mean wind, and MTOM required per year for A320 at Chios.

Table 5 Airports where payload does not change, but take-off distance required (TODR) does

\begin{tabular}{|c|c|c|c|c|c|}
\hline Airport & Years considered & $\begin{array}{l}\text { TODR at start, } \\
\text { MTOM (m) }\end{array}$ & $\begin{array}{l}\text { TODR at end, } \\
\text { MTOM }(\mathrm{m})\end{array}$ & Difference (m) & $\begin{array}{l}\text { Mean change } \\
\text { per year }(\mathrm{m})\end{array}$ \\
\hline Chania & $1955-2017$ & 1860 & 2014 & 154 & +2.5 \\
\hline Corfu & $1955-2015$ & 1789 & 1956 & 167 & +2.8 \\
\hline Iraklion & 1955-2017 & 2030 & 2088 & 58 & +0.9 \\
\hline Limnos & $1974-2017$ & 1753 & 1888 & 135 & +3.1 \\
\hline Mitilini & $1955-2016$ & 1980 & 2082 & 102 & +1.7 \\
\hline Rodos & $1955-2017$ & 1894 & 2062 & 168 & +2.7 \\
\hline Zakynthos & 1983-2017 & 1899 & 2016 & 117 & +3.4 \\
\hline
\end{tabular}


$t$ test), albeit again with slight revision (2.6 m.pa calculated using linear temperature trends, 2.4 m.pa calculated for each year then with a linear best fit determined.)

\subsection{Impact on a turbofan aeroplane}

Performance calculations were made at the airports of interest, except for Naxos, using a performance model for an Airbus A320 developed by the University of West London. Naxos' $900 \mathrm{~m}$ runway is too short for aeroplanes in this class at most conditions. Calculations of MTOM for the airport Chios where available payload changes and is most extreme were done for each year and plotted against time. Results are tabulated in Table 4 and depicted in Fig. 5. At Chios, the MTOM reduces by a mean of $133 \mathrm{~kg}$ per year over the considered period $\left(R^{2}=0.88, p=\right.$ $4.12 \times 10^{-21}$ using a two-tailed test, statistically significant), and at Skiathos, by a mean of $18 \mathrm{~kg}$ per year $\left(R^{2}=0.072, p=0.28\right.$ using a two-tailed test, statistical significance not proven) Table 5 .

\section{Conclusions}

Where runway length permits operating at maximum certified mass, at the Greek airports considered, climate change has increased take-off distance required (TODR) for the turboprop de Havilland DHC-8-400 aircraft by a mean of $1.4 \mathrm{~m}$ (about $0.1 \%$ ) per year during the periods for which data were available. The most adversely affected airport was Chios with an increase in TODR of $2.4 \mathrm{~m}$ or $0.2 \%$ pa. At Naxos, where the short runway normally precludes maximum take-off mass operations, the available payload per take-off has been reduced by about $3.0 \mathrm{~kg}$ (about $0.01 \%$ MTOM) per year for a similar period, since this type of aeroplane entered service in 1984, that equates to a nominal loss of revenue earning payload of $100 \mathrm{~kg}$ which would be about one average airline passenger with their baggage (Berdowski and et.al. 2009) per take-off for 2017 conditions. In the same time period, with a fully laden aeroplane, the type has suffered an average increase in take-off distance at the airports of interest ranging from in a best case of $10 \mathrm{~m}$ at Chania to a worst case of $89 \mathrm{~m}$ at Chios.

For the Airbus A320, a representative medium scale turbofan airliner, it was possible to operate at seven of the considered Greek airports at maximum certified mass - but take off distance has increased by a mean of $2.7 \mathrm{~m}$ (about $0.15 \%$ ) per year and in the worst case, Zakynthos by $3.4 \mathrm{~m}$ or $0.18 \%$ pa. At two airports, Chios and Skiathos, performance was runway limited, and available payload was reduced by a mean of $133 \mathrm{~kg}$ and $18 \mathrm{~kg}$ per year respectively, for the periods considered. Since the A320 entered service in 1988, for Chios, this equates to a mean loss of payload of $3900 \mathrm{~kg}$ or 38 standard passengers with baggage for 2017 conditions.

Therefore, we have shown that since at least 1955 climate change has been steadily degrading the performance of aircraft from the ten evaluated Greek airports - both at the turboprop and turbofan airliner scale. On longer runways take off distance increase, of an annual mean $0.1 \%$ for turboprop aircraft and $0.15 \%$ for turbofan is not impactful since it only increases take-off distances within the available runway length - although at higher temperature conditions it may become impactful. On shorter, but useable, runways where MTOM would normally be a function of runway length this becomes impactful by reducing the permissible payload-around $0.02 \%$ MTOM per year for turboprop aircraft, and about $0.12 \%$ of MTOM for the considered turbofan aircraft. In both cases, this is significant in terms of revenue earning payload - equivalent to 0.8 passengers with luggage per departure over the life of the DHC-8-400 at one airport (with loss of performance linear with time), and 
equivalent to 25 passengers with luggage for the A320 as the mean of two airports from the time the A320 was introduced to service. At Chios, the worst affected airport for the A320, this is $3990 \mathrm{~kg}$ since the aircraft was introduced in 1988: equivalent to 38 passengers with luggage, or fuel for $700 \mathrm{~nm}$ in the cruise (Park and O'Kelly 2014).

There are instances where, particularly, wind changes may force modification on the noise and pollution nuisance to areas around airports (possibly reducing it).

This enhances presently weak understanding of the impact of climate change on airports where maximum take-off mass is defined by runway length, and subsequently upon airports' stakeholders (e.g. tourist industries). Such airports are often critical to remote communities and tourist industries. There would be considerable value in repeating this study for comparable regions, for example the Caribbean or Scottish islands.

This study has also highlighted that previous, predictive work, had only considered temperatures in aeroplane performance. The incorporation of airport wind vectors may modify results, potentially in either a proverse or adverse manner (albeit for the ten Greek airports considered here, wind never reversed the adverse impact of temperature rise and impact was usually adverse). Incorporation of wind also gives the potential to predict noise and pollution nuisance changes to communities around airports.

Acknowledgments Gratton's work has been supported by the UK National Centre for Atmospheric Science. The Hellenic National Meteorology Service released meteorological data to S. Rapsomanikis.

Authors' contribution All authors have contributed to and approved this text and consider themselves equal joint authors.

Open Access This article is licensed under a Creative Commons Attribution 4.0 International License, which permits use, sharing, adaptation, distribution and reproduction in any medium or format, as long as you give appropriate credit to the original author(s) and the source, provide a link to the Creative Commons licence, and indicate if changes were made. The images or other third party material in this article are included in the article's Creative Commons licence, unless indicated otherwise in a credit line to the material. If material is not included in the article's Creative Commons licence and your intended use is not permitted by statutory regulation or exceeds the permitted use, you will need to obtain permission directly from the copyright holder. To view a copy of this licence, visit http://creativecommons.org/licenses/by/4.0/.

\section{References}

Aeronautical Supplies and Academics (ASA) Inc. (2018)The Pilot's Manual: Ground School: all the aeronautical knowledge required to pass the FAA exams and operate as a Private and Commercial Pilot (The Pilot's Manual Series Book 2), 4th Edn

Berdowski Z. et.al., Survey on standard weights of passengers and their baggage - final report, Reference EASA 2008.C.06/30800/R20090095/30800000/FBR/RLO, Zoetermeer, May 2009

Bombardier, (2011) Q400 DASH 8 Aeroplane Operating Manual AOM DSH 8-Q400, Rev. 27 (11 Feb )

Bombardier, (2014) Q400 DASH 8 Airport Planning Manual PSM 1-84-13, Revision 4 (5 Dec )

Coffel ED, Thompson TR, Horton RM (2017) The impacts of rising temperatures on aircraft takeoff performance. Clim Chang 144:381-388

Cranfield Aviation Training School (CATS),(2019) EASA Performance ATPL Guide,

Davy R, Esau I, Chernokulsky A, Outten S, Zilitinkevich S (2016) Diurnal asymmetry to the observed global warming. Int J Climatol. https://doi.org/10.1002/joc.4688

European Aviation Safety Authority, Airbus A318-319-320-321, Type Certificate Data Sheet No. EASA.A.064 Issue 36 (5 Nov 2018)

Federal Aviation Administration, Bombardier DHC-8-100 Series DHC-8-200 Series DHC-8-300 Series DHC-8400 Series, Type Certificate Data Sheet No. A13NM Revision 14 (April 9, 2004) 
Hellenic Civil Aviation Authority, AIP Greece, http://www.hcaa.gr/aip, accessed various dates up to 4 January 2019.

Irvine EA, Shine KP, Stringer MA (2016) What are the implications of climate change for trans-Atlantic aircraft routing and flight time? Transp Res Part D: Transp Environ 47:44-53. https://doi.org/10.1016/j. $\operatorname{trd} .2016 .04 .014$

Karnauskas KB, Donnelly JP, Barkley HC, Martin JE (2015) Coupling between air travel and climate. Nat Clim Chang 51:068-073

Lee SH, Williams PD, Frame THA (2019) Increased shear in the North Atlantic upper-level jet stream over the past four decades. Nature 572:639-642. https://doi.org/10.1038/s41586-019-1465-z

Lelieveld J, Hadjinicolaou P et al (2012) Climate change and impacts in the Eastern Mediterranean and the Middle East. Clim Chang 114(3-4):667-687. https://doi.org/10.1007/s10584-012-0418-4

McVicar TR et al (2012) Global review and synthesis of trends in observed terrestrial near-surface wind speeds: Implications for evaporation. JHydrology 416-417:182-205

Munasinghe L, Jun T, Rind DH (2012) Climate change: a new metric to measure changes in the frequency of extreme temperatures using record data. Clim Chang 113(iss 3-4):1001-1024

National Oceanographic and Atmospheric Administration, International Geomagnetic Reference Field (n.d.), https:/www.ngdc.noaa.gov/IAGA/vmod/igrf.html [accessed at various dates 2017 and 2018]

Park Y, O'Kelly ME (2014) Fuel burn rates of commercial passenger aircraft: variations by seat configuration and stage distance. JTransGeog 41:137-147. https://doi.org/10.1016/j.jtrangeo.2014.08.017

Pirazzoli PA, Tomasin A (2003) Recent near-surface wind changes in the central Mediterranean and Adriatic areas. Int J Climatol 23(8):963-973. https://doi.org/10.1002/joc.925

Storer LN, Williams PD, Joshi MM (2017) Global response of clear-air turbulence to climate change. Geophys Res Lett 44:9976-9984. https://doi.org/10.1002/2017GL074618

Swatton PJ (2008) Aircraft performance theory for pilots, 2nd edn. Wiley, Hoboken

Williams PD (2016) Transatlantic flight times and climate change. Environ Res Lett 11(2):024008. https://doi. org/10.1088/1748-9326/11/2/024008

Williams PD (2017) Increased light, moderate, and severe clear-air turbulence in response to climate change. Adv Atmos Sci 34(5):576-586. https://doi.org/10.1007/s00376-017-6268-2

Williams PD, Joshi MM (2013) Intensification of winter transatlantic aviation turbulence in response to climate change. Nat Clim Chang 3:644-648. https://doi.org/10.1038/nclimate1866

Zhou Y et al (2018) Decreased takeoff performance of aircraft due to climate change. Clim Chang 151:463-472

Publisher's note Springer Nature remains neutral with regard to jurisdictional claims in published maps and institutional affiliations.

\section{Affiliations}

\section{Guy Gratton ${ }^{1} \cdot$ Anil Padhra ${ }^{2} \cdot$ Spyridon Rapsomanikis $^{3} \cdot$ Paul D. Williams $^{4}$}

1 Cranfield University, Cranfield, Beds MK43 0AL, UK

2 University of West London, St Mary's Road, Ealing, London W5 5RF, UK

3 Unit of Environmental and Networking Technologies and Applications, ATHENA- RC, University Campus, Kimmeria, 67100 Xanthi, Greece

4 Department of Meteorology, University of Reading, Earley Gate, Reading, Berkshire RG6 6BB, UK 